\title{
КОНТРОЛЬ ИМУЩЕСТВЕННОГО ПОЛОЖЕНИЯ КАК МЕРА ПО ПРОТИВОДЕЙСТВИЮ КОРРУПЦИИ
}

K оррупция представляет глобальную угрозу для современного государства, подрывающую стабильность и безопасность общества, демократические институты и ценности. В современной научной литературе представлены два основных подхода к определению понятия коррупции. В узком (собственно юридическом) смысле коррупция рассматривается как совокупность составов правонарушений, предусмотренных в законодательстве РФ и отличающихся таким важным квалифицирующим признаком, как использование должностным лицом своего публичного статуса в корыстных целях для личного обогащения или в групповых интересах. В широком смысле это понятие охватывает негативное социальное явление, поразившее публичный аппарат управления. В последние десятилетия в международно-правовых документах возобладал еще более широкий подход, который можно рассматривать как универсальный, поскольку он включает не только публичную, но и частную сферу ${ }^{1}$.

В российском законодательстве коррупция определяется как злоупотребление служебным положением, дача взятки, получение взятки, злоупотребление полномочиями, коммерческий подкуп либо иное незаконное использование физическим лицом своего должностного положения вопреки законным интересам общества и государства в целях получения выгоды в виде денег, ценностей, иного имущества или услуг имущественного характера, иных имущественных прав для себя или для третьих лиц либо незаконное предоставление такой выгоды указанному лицу другими физическими лицами, а также совершение указанных деяний от имени или в интересах юридического лица².

По мнению ряда ученых, определение в действующем законодательстве коррупции через указание отдельных составов правонарушений является неэффективным, так как предусмотреть исчерпывающий перечень коррупционных деяний вряд ли возможно, поскольку разновидности такой деятельности посто-

\footnotetext{
1 Хабриева Т.Я. Научно-правовые проблемы противодействия коррупции // Журнал российского права. - 2012. - № 7 - С. 8.

2 Статья 1 Федерального закона от 25.12.2008 № 273-Ф3 “О противодействии коррупции".
}

янно совершенствуются, меняются в зависимости от средств противодействия ${ }^{3}$.

Одно из доктринальных определений коррупции предлагает профессор Т.Я. Хабриева. Под коррупцией она предлагает понимать «противоправное использование должностным или иным лицом своего положения в целях получения ненадлежащей выгоды для себя или третьих лиц, предоставления другими лицами такой выгоды, а также посредничество и иные формы содействия в совершении указанных деяний ${ }^{4}$.

Осуществление реформирования РФ, проводимое в последнее десятилетие, не могло не затронуть проблемы коррупции российского общества. В целях борьбы с этим негативным явлением человеческой цивилизации, разработан ряд нормативных правовых актов, устанавливающих систему мер, направленных на противодействие коррупции.

Противодействие коррупции, как деятельность федеральных органов государственной власти, органов государственной власти субъектов РФ, органов местного самоуправления, институтов гражданского общества, организаций и физических лиц, осуществляется по таким направлениям как профилактика коррупции, борьба с ней, а также минимизация и (или) ликвидация последствий коррупционных правонарушений.

Одной из мер, направленной на профилактику коррупции, является осуществление контроля со стороны государства за имущественным положением государственных служащих, лиц замещающих государственные должности.

Обязанность декларирования расходов установлена во многих странах. Подходы к выбору источников закрепления соответствующих норм различаются. Необходимость такого декларирования закрепляется на законодательном и подзаконном уровне, в актах, определяющих статус органов представительной власти, о государственной и муниципальной службе, затрагивающих вопросы налогообложения, финансового контроля. А также в кодексах поведения различных категорий должност-

\footnotetext{
Цирин А.М. Противодействие коррупции в Российской Федерации: проблемы правового регулирования // Журнал российского права. - 2012. - № 12. - С. 48.

4 Хабриева Т.Я. Указ. раб. - С. 9.
} 
ных лиц, актах, определяющих меры противодействия коррупции. Примеры можно найти в законодательстве США, Великобритании, Бельгии, Италии, Финляндии, Канады и других государств. В то же время проблемными вопросами остаются: определение объектов декларирования; определение субъектов декларирования сведений о расходах (представляется излишним требование о декларировании расходов всеми без исключений государственными служащими, поскольку в таком случае осуществить полноценную проверку деклараций невозможно); обеспечение контроля за предоставлением сведений о расходах (могут привлекаться налоговые органы, органы финансового мониторинга, высшие органы финансового контроля и др. $)^{5}$.

В российском законодательстве данная мера для «широкого» применения была установлена Федеральным законом от 27.07.2004 г. № 79-Ф3 «О государственной гражданской службе Российской Федерации», где была определена обязанность гражданина при поступлении на гражданскую службу, а также самого гражданского служащего ежегодно представлять нанимателю сведения о доходах, об имуществе и обязательствах имущественного характера.

Важным событием в истории антикоррупционного законодательства России стала ратификация ${ }^{6}$ Конвенции ООН против коррупции от 31.10.2003 г. В принятом в этой связи Федеральном законе от 25.12.2008 г. № 280Ф3 «О внесении изменений в отдельные законодательные акты Российской Федерации в связи с ратификацией Конвенции ООН против коррупции от 31 октября 2003 года и Конвенции об уголовной ответственности за коррупцию от 27 января 1999 года и принятием Федерального закона «О противодействии коррупции»», контроль со стороны государства за имущественным положением государственных служащих усилился. По данному закону, гражданин, претендующий на замещение должности гражданской службы, а также гражданский служащий, замещающий должность гражданской службы, обязаны ежегодно представлять представителю нанимателя сведения не только о своих доходах, имуществе и обязательствах имущественного характера, но также о доходах, об имуществе и обязательствах имущественного характера членов своей семьи (супруги (супруга) и несовершеннолетних детей). Такое усиление контроля со стороны государства коснулось не только гражданской службы, но и лиц, занимающих должности в органах и учреждениях

\footnotetext{
Мусаелян М.Ф. Правовые проблемы противодействия коррупции / М.Ф. Мусаелян, М.А. Хатаева // Журнал российского права. - 2012. - № 1. - С. 111-112.

6 Федеральный закон от 08.03.2006 № 40-Ф3 “О ратификации Конвенции Организации Объединенных Наций против коррупции».
}

прокуратуры, сотрудников органов внутренних дел, сотрудников таможенных органов, судебных приставов, военнослужащих. В нормативные правовые акты, закрепляющиех статус указанных служащих были внесены нормы, согласно которым на эти категории «распространяются ограничения, запреты и обязанности, установленные Федеральным законом «О противодействии коррупции» и статьями 17, 18 и 20 Федерального закона от 27 июля 2004 года № 79-Ф3 «О государственной гражданской службе Российской Федерации»».

Механизмы контроля за имущественным положением близких родственников государственного служащего активно применяются в ряде государств. Так, в частности, в США декларации о доходах и имуществе в том же режиме, что и сам чиновник, подают его супруга (супруг). На близких родственников служащего распространяются ограничения и запреты на получение подарков и осуществление трудовой деятельности".

Вместе с тем, ряд ученых указывает на сложности, которые могут возникнуть в связи с выполнением со стороны государственного служащего своей обязанности по предоставлению сведений о доходах, имуществе и обязательствах имущественного характера своей супруги (супруга), так как получение такой информации, по сути, возможно только при согласии супруги (супруга). В этой связи возникает вопрос о возможности предоставления такой информации в случае, ели согласие супруги (супруга) отсутствует, а также достоверности предоставленной информации ${ }^{8}$. Предлагается внести в законодательные акты норму, устанавливающую право служащего на обращение к представителю нанимателя (работодателю) с соответствующим заявлением об истребовании в компетентных органах сведений о доходах, имуществе и обязательствах имущественного характера, которые сам служащий не имеет возможности получить, установив при этом обязанность органов и лиц, располагающих указанными сведениями, предоставить их по запросу представителя нанимателя9 .

Формирование антикоррупционного законодательства продолжилось принятием Указа Президента РФ от 18.05.2009 № 55910, в котором был определен порядок

\footnotetext{
См.: Куракин А.В. Административные запреты и проблемы борьбы с коррупцией в системе государственной гражданской службы // СПС «КонсультантПлюс»; Николайчик, В.М. Правовое регулирование этики официальных лиц в США //США: экономика, политика, идеология. - 1998. - № 5. - С. 88.

8 Сараев Н.В. О некоторых вопросах применения законодательства России о противодействии коррупции // Административное и муниципальное право. - 2010. - № 6. - С. 77-78.

9 Сараев Н.В. Указ раб. - С. 79.

10 Указ Президента РФ от 18.05.2009 № 559 (ред. от 13.03.2012) “О представлении гражданами, претендующими на замещение
} 
представления гражданами, претендующими на замещение должностей федеральной государственной службы, и федеральными государственными служащими сведений о полученных ими доходах, об имуществе, принадлежащем им на праве собственности, и об их обязательствах имущественного характера, а также сведений о доходах супруги (супруга) и несовершеннолетних детей, об имуществе, принадлежащем им на праве собственности, и об их обязательствах имущественного характера.

Указом Президента РФ от 21.09.2009 № $1065^{11}$ был определен порядок осуществления проверки:

а) достоверности и полноты сведений о доходах, об имуществе и обязательствах имущественного характера, представляемых в соответствии с Указом Президента РФ от 18 мая 2009 г. № 559 гражданами, претендующими на замещение должностей федеральной государственной службы, на отчетную дату, а также федеральными государственными служащими по состоянию на конец отчетного периода;

б) достоверности и полноты сведений, представляемых гражданами при поступлении на федеральную государственную службу в соответствии с нормативными правовыми актами РФ;

в) соблюдения государственными служащими ограничений и запретов, требований о предотвращении или урегулировании конфликта интересов, исполнения ими обязанностей, установленных Федеральным законом от 25 декабря 2008 г. № 273-Ф3 «О противодействии коррупции» и другими федеральными законами.

В данных указах подробно регламентируется порядок реализации обязанности служащего по представлению необходимой информации, а также порядок осуществления контроля за выполнением этой обязанности, что позволяет сделать вывод о формировании не только материальных, но и процессуальных норм в рамках института контроля со стороны государства за имущественным положением государственных служащих и лиц, замещающих государственные должности.

Следующим этапом, направленным на усиление со стороны государства контроля имущественного положения государственного служащего, стало принятие ряда охранительных норм, направленных на выполнение ра-

должностей федеральной государственной службы, и федеральными государственными служащими сведений о доходах, об имуществе и обязательствах имущественного характера".

11 Указ Президента РФ от 21.09.2009 № 1065 (ред. от 13.03.2012) “О проверке достоверности и полноты сведений, представляемых гражданами, претендующими на замещение должностей федеральной государственной службы, и федеральными государственными служащими, и соблюдения федеральными государственными служащими требований к служебному поведению”. нее принятых обязанностей. Так, Федеральным законом от 21.11.2011 № 329-Ф3 «О внесении изменений в отдельные законодательные акты Российской Федерации в связи с совершенствованием государственного управления в области противодействия коррупции», была установлена норма, определяющая, что непредставление гражданским служащим сведений о своих доходах, об имуществе и обязательствах имущественного характера, а также о доходах, об имуществе и обязательствах имущественного характера своих супруги (супруга) и несовершеннолетних детей в случае, если представление таких сведений обязательно, либо представление заведомо недостоверных или неполных сведений является правонарушением, влекущим увольнение гражданского служащего с гражданской службы ${ }^{12}$. Ярко выраженный императивных характер вновь принятых норм указывает на особую заинтересованность со стороны государства в соблюдении и выполнении требований, закрепляющих обязанность по представлению сведений об имущественном положении служащих и лиц, замещающих государственные должности.

Судебная практика свидетельствует о том, что данные охранительные нормы активно применяются. Так, В., проходил службу на должности начальника отделения надзорной деятельности Главного управления МЧС по Волгоградской области. С 31 марта 2011 г. он находился в очередном отпуске, в связи с чем пропустил срок (до 30 апреля 2011 г.) предоставления сведений о доходах, об имуществе и обязательствах имущественного характера, определенный указом Президента РФ от 8.05.2009 № 559. В. предоставил такие сведения по выходу из отпуска, в связи с чем был уволен из государственной противопожарной службы за грубое нарушение служебной дисциплины. Суд при рассмотрении дела определил, что нормами установлен конкретный срок предоставления сведений о доходах, об имуществе и обязательствах имущественного характера. Следовательно, в случае нарушения установленного законом срока такие сведения считаются не представленными. Суд установил, что в действиях В. имеется состав грубого дисциплинарного проступка ${ }^{13}$.

12 Пункт 6.1 ст. 20 Федерального закона от 27.07.2004 № 79-Ф3 “О государственной гражданской службе Российской Федерации”.

13 Апелляционное определение Волгоградского областного суда от 27.06.2012 по делу № 33-6142/12 в удовлетворении иска о признании незаконной процедуры увольнения, восстановлении в прежней должности и обязании выплатить денежное довольствие отказано, так как в действиях истца имеется состав грубого дисциплинарного проступка; нарушений при применении дисциплинарного наказания в виде увольнения допущено не было. 
Б. проходил федеральную государственную гражданскую службу в должности начальника отдела организации прибрежного рыболовства и внутренних водоемов Управления организации рыболовства Росрыболовства. Приказом от 15 февраля 2012 г. действие служебного контракта с Б. прекращено, истец освобожден от занимаемой должности и уволен в связи с утратой доверия по причине представления гражданским служащим заведомо неполных сведений о своих доходах, об имуществе и обязательствах имущественного характера (п. 1 ч. 1 ст. 59.2 Федерального закона от 27 июля 2004 г. № 79-Ф3 «О государственной гражданской службе Российской Федерации»).

Основанием для увольнения послужило решение комиссии Росрыболовства по соблюдению требований к служебному поведению федеральных государственных гражданских служащих и урегулированию конфликта интересов, принятое по результатам рассмотрения материалов проверки. Комиссией установлено представление Б. неполных сведений о доходах, об имуществе и обязательствах имущественного характера и рекомендовано руководителю Росрыболовства уволить Б. в связи с утратой доверия. Приказом от 22 ноября 2011 г. на основании информационного письма ФСБ России от 21 ноября 2011 г. в отношении истца назначено проведение проверки по факту возможного предоставления неполных сведений о доходах, об имуществе и обязательствах имущественного характера.

Проверкой было установлено, что у Б. в период службы в Росрыболовстве имелись счета банковских карт, на которые производились безналичные зачисления денежных средств от физических лиц ${ }^{14}$.

Вновь принимаемые нормативные правовые акты по вопросам государственной службы полностью заимствуют установленную модель контроля со стороны государства за имущественным положением государственных служащих. Так, в Федеральном законе от 07.02.2011 г. № 3-ФЗ «О полиции» закреплена обязанность сотрудника полиции представлять в порядке, установленном законодательством РФ, сведения о своих доходах, об имуществе и обязательствах имущественного характера, а также сведения о доходах, об имуществе и обязательствах имущественного характера своих супруги (супруга) и несо-

14 Апелляционное определение Московского городского суда от 20.09.2012 по делу № 11-22664 в удовлетворении иска о восстановлении на работе, взыскании заработной платы, компенсации морального вреда отказано правомерно, так как истец, являясь госслужащим, представил заведомо неполные сведения о своих доходах, указанное обстоятельство являлось основанием для увольнения истца в связи с утратой доверия, при этом должность истца включена в перечень должностей, при замещении которых госслужащие обязаны представлять сведения о своих доходах. вершеннолетних детей ${ }^{15}$. Непредставление сотрудником таких сведений (представление заведомо недостоверных или неполных сведений) относится к грубым нарушениям служебной дисциплины и является основанием для расторжения с сотрудником контракта и увольнением со службы в органах внутренних дел ${ }^{16}$.

Следующим этапом развития и совершенствования противокоррупционных мер по контролю за имущественным положением лиц, замещающих государственные должности, стало принятие Федерального закона от 03.12.2012 г. № 230-Ф3 «О контроле за соответствием расходов лиц, замещающих государственные должности, и иных лиц их доходам». Как следует из названия, закон устанавливает правовые и организационные основы осуществления контроля за соответствием расходов лица, замещающего государственную должность, расходов членов его семьи общему доходу данного лица и его супруги (супруга) за три последних года, предшествующих сделке. Речь идет о сделке по приобретению земельного участка, другого объекта недвижимости, транспортного средства, ценных бумаг, акций, если сумма сделки превышает общий доход данного лица и его супруги (супруга) за три последних года, предшествующих совершению сделки.

По мнению В.Д. Зорькина, переход от декларирования доходов к декларированию расходов позволит в большей степени, чем сейчас, обеспечить прозрачность, в том числе и финансовую. При этом, В.Д. Зорькин не исключает возможности, «что в какой-то части бремя доказывания невиновности может лежать не на государстве, а на самом лице, действие которого подвергается сомнению (так как ему необходимо доказать, что у него легальные источники доходов) ${ }^{17}$.

Работа по совершенствованию законодательства в области противодействия коррупции продолжается. Группой депутатов в Государственную Думу РФ представлен законопроект ${ }^{18}$ о внесении изменений в Федеральный закон «О противодействии коррупции». В указанном законопроекте установлено, что «лицам, замещающим государственные должности РФ, государственные должности субъектов РФ, муниципальные должности, проходящим военную службу, сотрудникам органов внутренних дел,

15 Пункт 10, ч. 1 ст. 27 Федерального закона от 07.02.2011 № 3-ФЗ “О полиции”.

16 Статьи 49, 82 Федерального закона от 30.11.2011 № 342Ф3 (ред. от 03.12.2012) “О службе в органах внутренних дел Российской Федерации и внесении изменений в отдельные законодательные акты Российской Федерации".

17 Зорькин В.Д. Коррупция как угроза стабильному развитию общества // Журнал российского права. - 2012. - № 7. - С. 19.

18 Проект Федерального закона № 120809-6 «О внесении изменений в отдельные законодательные акты Российской Федерации». 
учреждений и органов уголовно-исполнительной системы, органов по контролю за оборотом наркотических средств и психотропных веществ, таможенных органов, Следственного комитета РФ, работникам органов прокуратуры РФ, государственным и муниципальным служащим, а также их супруге (супругу) и несовершеннолетним детям, если иное не обусловлено решением задач служебной (должностной) деятельности, запрещается:

1) иметь вклад (депозит), счет в иностранном банке на территории иностранного государства, и (или) иметь в собственности недвижимое имущество за границей, и (или) иметь в собственности ценные бумаги иностранной компании;

2) открывать вклад (депозит), счет в иностранном банке на территории иностранного государства, и (или) приобретать в собственность недвижимое, имущество за границей, и (или) приобретать в собственность ценные бумаги иностранной компании»?

Одновременно в законопроекте содержится и охранительные нормы, предусматривающие внесение изменения в УК РФ в части, устанавливающей уголовную ответственность за несоблюдение вышеуказанных запретов. Предлагается дополнить УК РФ ст. 289.1. «Нарушение запрета, установленного законом в отношении иностранного счета и (или) имущества». В качестве санкции в статье предлагается установить штраф в размере от пяти до десяти миллионов рублей или лишение свободы сроком до пяти лет с лишением права занимать определенные должности на срок до трех лет.

Делать вывод о том, что процесс становление законодательство о противодействии коррупции завершился, преждевременно. Анализ принятых за последние годы нормативных правовых актов позволяет прийти к выводу, что совершенствование правового регулирования в области противодействия коррупции осуществляется в направлении ужесточения контроля со стороны государства за деятельностью государственных служащих и лиц, замещающих государственные должности, и в частности, за их имущественным положением.

Ужесточение контроля со стороны государства осуществляется не только путем расширения круга лиц, на которых распространяются определенные имущественные ограничения и запреты, но и путем увеличения объема такого контроля.

\section{Библиографический список:}

1. Зорькин В.Д. Коррупция как угроза стабильному развитию общества // Журнал российского права. - 2012 . - № 7.

2. Куракин А.В. Административные запреты и проблемы борьбы с коррупцией в системе государственной гражданской службы // Российская юстиция. - 2008. - № 4.

3. Мусаелян М.Ф. Правовые проблемы противодействия коррупции / М.Ф. Мусаелян, М.А. Хатаева // Журнал российского права. - 2012. - № 1.

4. Николайчик В.М. Правовое регулирование этики официальных лиц в США // США: экономика, политика, идеология. - 1998. - № 5 .

5. Сараев Н.В. О некоторых вопросах применения законодательства России о противодействии коррупции // Административное и муниципальное право. - 2010. - № 6.

6. Хабриева Т.Я. Научно-правовые проблемы противодействия коррупции // Журнал российского права. 2012. - № 7.

7. Цирин А.М. Противодействие коррупции в Российской Федерации: проблемы правового регулирования // Журнал российского права. - 2012. - № 12.

\section{References (transliteration):}

1. Zor'kin V.D. Korruptsiya kak ugroza stabil'nomu razvitiyu obshchestva // Zhurnal rossiyskogo prava. - 2012 . - № 7.

2. Kurakin, A.V. Administrativnye zaprety i problemy bor'by s korruptsiey $v$ sisteme gosudarstvennoy grazhdanskoy sluzhby // Rossiyskaya yustitsiya. 2008. № 4.

3. Musaelyan M.F. Pravovye problemy protivodeystviya korruptsii / M.F. Musaelyan, M.A. Khataeva // Zhurnal rossiyskogo prava. - 2012. - № 1 .

4. Nikolaychik V.M. Pravovoe regulirovanie etiki ofitsial'nykh lits v SShA / V.M. Nikolaychik // SShA: ekonomika, politika, ideologiya. - 1998. - № 5.

5. Saraev N.V. O nekotorykh voprosakh primeneniya zakonodatel'stva Rossii o protivodeystvii korruptsii // Administrativnoe i munitsipal'noe pravo. - 2010. - № 6 .

6. Khabrieva T.Ya. Nauchno-pravovye problemy protivodeystviya korruptsii // Zhurnal rossiyskogo prava. - 2012. - № 7.

7. Tsirin A.M. Protivodeystvie korruptsii v Rossiyskoy Federatsii: problemy pravovogo regulirovaniya // Zhurnal rossiyskogo prava. - 2012. - № 12. 